\title{
Folate Enrichment of Ogi (a Fermented Cereal Gruel) Using Folate Producing Starter Cultures
}

\author{
Ike Okoroafor'1, Kolawole Banwo ${ }^{1}$, Afolake Atinuke Olanbiwoninu ${ }^{2,3^{*}}$, \\ Sunday Ayodele Odunfa ${ }^{1}$ \\ ${ }^{1}$ Department of Microbiology, University of Ibadan, Ibadan, Nigeria \\ ${ }^{2}$ Department of Biological Sciences, Ajayi Crowther University, Oyo, Nigeria \\ ${ }^{3}$ Laboratory of Food Biotechnology, Institute of Food Nutrition and Health, ETH Zurich, Zurich, Switzerland \\ Email: *flakyolanbiwonninu@yahoo.com
}

How to cite this paper: Okoroafor, I., Banwo, K., Olanbiwoninu, A.A. and Odunfa, S.A. (2019) Folate Enrichment of Ogi (a Fermented Cereal Gruel) Using Folate Producing Starter Cultures. Advances in Microbiology, 9, 177-193. https://doi.org/10.4236/aim.2019.93014

Received: January 21, 2019

Accepted: March 2, 2019

Published: March 5, 2019

Copyright () 2019 by author(s) and Scientific Research Publishing Inc. This work is licensed under the Creative Commons Attribution International License (CC BY 4.0).

http://creativecommons.org/licenses/by/4.0/

\section{(c) (i) Open Access}

\begin{abstract}
This study was aimed at selecting starter cultures for bio-enriching ogi (fermented cereal gruel) using folate-producing microorganisms. The folate-producing microorganisms were isolated by incorporating folate analogue, methotrexate in the isolation medium and further screened for folate production by growth in Folic Acid Casei Medium. Folate production was quantified using 3-aminophenol spectrophotometric method. Folate-producing lactic acid bacteria from fermenting maize slurry were species of Lactobacillus, Lactococcus, Pediococcus and Leuconostoc while yeast isolates were mainly species of Candida and Saccharomyces. However, Lactobacillus plantarum X13, Pediococcus pentosaceus L73, Candida parapsilosis Y77 and Candida tropicalis Y74 were used as starter cultures singly and in combination for the fermentation and production of $\mathrm{ogi}$. The highest folate concentration, $30.97 \pm 0.37 \mu \mathrm{g} / \mathrm{ml}$, was observed after $24 \mathrm{~h}$ of the co-fermentation of maize slurry with Lactobacillus plantarum X13 and Candida tropicalis Y74. This represents a triple fold of the folate concentration observed in unfermented maize slurry. The $\mathrm{pH}$ of the fermenting maize slurry was observed to decrease from 6.12 to 3.60 , while the reducing sugars and the titratable acidities were observed to increase as fermentation progressed. Sensory evaluation of the ogi samples after fermentation showed high general acceptability comparable to the naturally fermented ogi as regards to colour, taste, flavour, aroma and texture. The data made available in this study suggest the possibility of folate enrichment of ogi and its use as a vehicle for increasing folate availability to consumers thereby preventing folate deficiency diseases prevalent in many African countries.
\end{abstract}

\section{Keywords}

Folate Producers, Folate Enrichment, Ogi, Lactic Acid Bacteria, Yeasts 


\section{Introduction}

Cereal based fermented foods constitute a major part of our diets in West Africa [1]. These fermented foods are produced from staple grains such as millet, maize and sorghum which are consumed mostly as main course meals or as beverages [2] [3] [4]. Ogi known as Akamu is a Nigerian traditional lactic acid fermented cereal-based meal, made basically from maize (Zea mays), and other cereals such as sorghum or millet [4].

During the traditional process of ogi production, there had been reports of nutrients loss of approximately $20 \%-50 \%$ from the original cereal grains [2] [5]. The nutrients implicated are amino acids such as lysine and tryptophan while vitamins such as riboflavin and folate [2]. Maize in its raw form contain very low amount of folate, $19 \mu \mathrm{g} / 100 \mathrm{~g}$ fresh weight [6]. Certain factors like adverse $\mathrm{pH}$, high temperature, and presence of oxidizing agents have been implicated in the loss of folate during food processing [7] [8]. Folate is an important vitamin needed during the early pregnancy stages when embryo is rapidly growing. It is an essential vitamin for DNA synthesis and methylation reactions and prevents neural tube defects in the developing foetus [9] [10]. The deficiency is implicated in megaloblastic anaemia, cardiovascular diseases and other health disorders [11] [12] [13]. Folic acid is only produced by chemical synthesis. Hence, the use of folate produced through natural means is innovative in the proposed study; biotechnological production using fermentation organisms in enriching ogi is being studied. Fortification of food with folic acid has shown positive results in South Africa in 2008 where the South African Medical Research Council observed a $33 \%$ decline in the incidence of neural tube defects due to the increased availability and consumption of adequately fortified folic acid maize cereal. The approach of using microbes in bio-enriching foods has been carried out in many foods; for example high lysine ogi was produced at pilot scale using lysine and methionine-overproducing yeasts and lactic acid bacteria strains [2]. It has been demonstrated that folate levels in togwa, a Tanzanian fermented maize-based porridge, consumed in rural areas in Tanzania can be increased by $700 \%$ during fermentation with yeasts originally isolated from togwa [14]. Bacteria obtained during fermentation of cereal-based products are capable of producing folate in the culture medium [15] [16]. An increase in the folate content of ben salaaga of Burkina Faso, a cereal based fermented gruel when co-fermented with Lactobacillus fermentum and strains of Pichia kudriavzevii had been reported [17]. Therefore, considering the high consumption of ogi as a weaning food and even among convalescing adults, its folate enrichment presents a biologically efficient and nutritional functional means for folate supplementation. Though lactic acid fermentation mediated by lactic acid bacteria and yeast is considered as cell factory for the production of bioactive compounds especially folate and riboflavin [7], most published findings have concentrated on dairy fermented products at the expense of cereal based fermented foods. The aim of this study is to bio-enrich ogi with folate producing microorganisms as starter cultures. To this end, fo- 
late-producing microorganisms were isolated during the fermentation of maize for ogi production. The folate-producing capacities of the isolates were measured and used as starter cultures for the laboratory scale controlled fermentation of ogi.

\section{Materials and methods}

\subsection{Isolation of Folate-Producing Microorganisms}

The isolation of microorganisms from fermenting maize slurry was done using the pour plate method as described by Harrigan and McCance [18]. Nine milliliters $(9 \mathrm{ml})$ of distilled water was dispensed into washed test tubes, autoclaved at $121^{\circ} \mathrm{C}$ for $15 \mathrm{~min}$ and allowed to cool. One $\mathrm{ml}$ of the fermenting maize slurry was serially diluted in sterile distilled water and pour plated using deMann Rogosa and Sharpe (MRS) agar (LabM, Lancashire, United Kingdom) for lactic acid bacteria and malt extract agar (LabM, UK) for yeasts. Methotrexate (Zuthrex, Germany) a folic acid analogue was added to the media at a concentration of $50 \mathrm{mg} / \mathrm{ml}$ aseptically, after cooling to about $40^{\circ} \mathrm{C}$. This is to select for folate producing microorganisms from the samples. Incubation was at $30^{\circ} \mathrm{C} \pm 5^{\circ} \mathrm{C}$ for $48 \mathrm{~h}$ for lactic acid bacteria and for yeasts. After incubation, the plates were observed for growth of distinct colonies, which were counted and randomly selected and streaked to obtain pure culture.

\subsection{Phenotypic Characterisation of the LAB and Yeast Isolates}

The LAB and yeast isolates were characterised based on the study of morphological and biochemical properties as described by Harrigan and McCance [18] and Kurtzman et al. [19] respectively. The presumptive identification of lactic acid bacteria isolates was done with the use of the Genera of Lactic Acid Bacteria [20]. Yeasts isolates were identified according to Kurtzman et al. [19].

\subsection{Screening of Folate Production and Quantification in Culture Medium}

Isolates obtained were screened for folate production using the method of $\mathrm{Ru}$ engsitagoon and Hattanat [21]. Briefly, the isolates were grown in their respective broth and incubated for $48 \mathrm{~h}$, after which the broth were centrifuged at $3000 \mathrm{~g}$ for $20 \mathrm{~min}$. One $\mathrm{ml}$ of the supernatant was mixed with $1 \mathrm{ml}$ of $4 \mathrm{~mol} \cdot \mathrm{L}^{-1}$ hydrochloric acid, $1 \mathrm{ml}$ of $1 \%(\mathrm{w} / \mathrm{v})$ sodium nitrate, $1 \mathrm{ml}$ of $1 \%(\mathrm{w} / \mathrm{v})$ of sulfamic acid and $1 \mathrm{ml}$ of $1 \%(\mathrm{w} / \mathrm{v})$ of 3 -amino phenol, which resulted in an orange-yellow complex, indicating the presence of folate. The absorption of complexation was measured at $460 \mathrm{~nm}$ using UV visible spectrophotometer (Jenway, Essex, UK). The concentration of folates in samples was deduced from the standard curve prepared using the absorbance of known concentration of folic acid.

The folate producing ability of the isolates was further determined by inoculating them into Folic Acid Casei Medium. Folic Acid Casei Medium (FACM) is an assay medium containing all the ingredients and essential nutrient for the 
growth of the test organism except folic acid [22]. Isolates that grew in this chemically defined medium were considered potential folate producers. Three independent experiments were carried out.

\section{Safety Assessments of the Selected Isolates}

\subsection{Production of Haemolysis, Gelatinase and DNase}

The isolates were cultured in MRS and ME broth at $37^{\circ} \mathrm{C}$ for $12-18 \mathrm{~h}$ and then streaked onto blood agar (Difco, Michigan, USA) plates supplemented with 5\% defibrinated whole sheep blood [23] [24]. After 24 to $48 \mathrm{~h}$, the haemolytic reaction was recorded. Gelatinase production was determined by point inoculation of pure $\mathrm{LAB}$ and yeast isolates on plate containing tryptone-neopeptone-dextrose (TND) agar supplemented with $0.4 \%$ gelatin. The plates were incubated at $37^{\circ} \mathrm{C}$ for $48 \mathrm{~h}$ and then flooded with saturated ammonium sulfate solution. Development of clear zones around the spots against the opaque background indicated a positive reaction. DNase agar medium was used to check production of DNase enzyme. Pure $\mathrm{LAB}$ and yeast isolates were streaked on the plates and incubated at $30^{\circ} \mathrm{C}$ for $48 \mathrm{~h}$. A clear pinkish zone around the colonies against dark blue background was considered as positive for DNase production [25].

\subsection{Genotypic Characterisation of the Selected LAB and Yeast Strains}

The genomic DNA of the selected LAB isolates was extracted using the Wizard O Genomic DNA Purification kit (Promega, Dübendorf, Switzerland) according to the manufacturer's protocol. The genomic DNA of the selected yeasts was extracted using the instantgen matrix method described by Kurtzman and Robnett [26]. The partial 16S rRNA and 28S rRNA region of the nucleotide sequence of LAB and yeast were amplified by PCR. Primers designed for lactic acid bacteria was bak11w (5'-AGT TTG ATC MTG GCT CAG-3') and bak4 (5'-AGG AGG TGA TCC ARC CGC A-3') while for yeast the forward was (5'-GCA TAT CAA GCG GAG GAA AAG-3') and reverse (5'-GGT CCG TGT TTC AAG ACG G-3') [27] [26]. The PCR protocol used was performed with a PCR thermal cycler (biometra T3000 thermocycler, BIOLABO). The final reaction mixture $(20 \mu \mathrm{l})$ contained $220 \mu \mathrm{L}$ PCR MASTER MIX 2X, $4.4 \mu \mathrm{L}$ of primers, $189.2 \mu \mathrm{L}$ of water and $1 \mu \mathrm{l}$ of template DNA. Amplification consisted of initial denaturation at $95^{\circ} \mathrm{C}$ for $5 \mathrm{~min}$, followed by 35 cycles of $95^{\circ} \mathrm{C}$ for $30 \mathrm{~s}, 60^{\circ} \mathrm{C}$ for $30 \mathrm{~s}$, and $72^{\circ} \mathrm{C}$ for $45 \mathrm{~s}$, and a final $7 \mathrm{~min}, 72^{\circ} \mathrm{C}$ extension followed, with a final hold at $4^{\circ} \mathrm{C}$. The PCR products were analyzed on a $1 \%(\mathrm{wt} / \mathrm{vol})$ agarose gel, and electrophoresis was performed for $2 \mathrm{~h}$ at $60 \mathrm{v}$ and the gel image was photographed using a BIORAD molecular imager. All PCR products for subsequent sequencing reactions were purified with the Wizard SV Gel and PCR Clean-Up System kit (Promega, Madison, USA) according to the manufacturer's instructions and subsequently sequenced in GATC laboratory (Konstanz, Germany). The sequences were submitted to Genbank and accession numbers assigned to each. 


\subsection{Laboratory Production of Ogi for Controlled Fermentation}

Maize grains were sorted and washed three times using distilled water. The grains were steeped in water for 2 days, oven dried at $50^{\circ} \mathrm{C}$ for $24 \mathrm{~h}$, dry milled into flour and sieved in order to obtain fine flour. Thirty grammes of the flour was weighed into clean glass containers and sterilized at $120^{\circ} \mathrm{C}$ for $20 \mathrm{~min}$. After sterilization, $70 \mathrm{ml}$ of the sterile water was added aseptically to the sterile fine flour.

\subsection{Inoculum Preparation for Controlled Fermentation of Ogi}

The selected folate producing lactic acid bacteria and yeast strains were cultured on malt extract and MRS broth and incubated for $24-48 \mathrm{~h}$. The broth cultures were centrifuged at $2000 \mathrm{~g}$ for $10 \mathrm{~min}$. After which, the cell pellets were washed thrice using sterile distilled water and used as inoculum for the fermentation. The numbers of organisms per ml of suspension was estimated using $0.5 \mathrm{Mcfar}-$ land standard and approximated to be $1 \times 10^{8} \mathrm{cfu} / \mathrm{ml}$.

\subsection{Controlled Fermentation of Ogi Using the Selected Strains}

A $1 \%$ inoculum size representing approximately $10^{8} \mathrm{cfu} / \mathrm{ml}$, of the yeast and lactic acid bacteria strains were aseptically pitched into the maize flour-water mixture (singly and in combination), this was thoroughly shaken and allowed to ferment for $24-72 \mathrm{~h}$ [2]. The fermented maize slurry samples designated as Samples A to $\mathrm{F}$ were fermented with the selected starter cultures singly and combination while the spontaneously fermented maize sample was Sample G.

\subsection{Microbial Count of the Selected Strains in the Fermenting Maize Slurry}

One millilitre of each of the fermenting slurry was introduced into the sterile distilled water in test tubes and serially diluted. One millilitre of the different dilutions were pour plated into the appropriate media. De Mann Rogosa and Sharpe (MRS) agar for lactic acid bacteria and malt extract agar for yeast. After incubation, the plates were observed for growth and distinct colonies were counted. This was carried out at 24-h interval during fermentation [2].

\subsection{Determination of $\mathrm{pH}$ and Titratable Acidity of the Fermenting Maize Slurry}

The changes in $\mathrm{pH}$ as the fermentation progressed were measured using a $\mathrm{pH}$ meter (Mettler-Toledo, Essex, UK) with a reference glass electrode. The $\mathrm{pH}$ meter was calibrated prior to each reading using buffers of $\mathrm{pH}$ of 7 and 4.

The total titratable acidity of the fermenting ogi samples was determined by titrating $5 \mathrm{ml}$ of each sample against $0.1 \mathrm{M} \mathrm{NaOH}$ using 2 drops of phenolphthalein as indicator. A $0.1 \mathrm{M} \mathrm{NaOH}$ was added to the sample until a pink colour was obtained. The total titratable acidity was calculated as the amount of lactic acid produced [28]. Three independent assays were carried out. 


\subsection{Determination of Total Reducing Sugars}

The total reducing sugar was determined using the DNS (3,5-Dinitrosalicyclic acid, Sigma-Aldrich, MO, USA) method as described by Miller [29]. A volume of $3 \mathrm{ml}$ of DNS reagent was added to $1 \mathrm{ml}$ of the sample (aliquot) in a lightly capped test tube. The mixture was heated for 5 - 15 min until it developed a red-brown color. One $\mathrm{ml}$ of $40 \%$ potassium sodium tartrate (Rochelle salt) solution was added to stabilize the color. Sample was cooled to room temperature and the absorbance of the samples was read at $575 \mathrm{~nm}$ using a UV visible spectrophotometer. Three independent assays were carried out.

\subsection{Determination of Folate Concentration}

The folate concentration after fermentation was carried out as stated above according to Ruengsitagoon and Hattanat [21] with slight modifications. Two independent experiments were carried out.

\section{Sensory Analysis}

This was carried out to determine the sensory qualities of the folate enriched ogi. A 10-man panel that are familiar with ogi was asked to assess ogi samples produced using the folate-producers as starters for colour, aroma, taste, flavour and overall acceptability in comparison with the spontaneously fermented ogi. The samples were rated based on a 9-point hedonic scale, which ranged from $9=$ like extremely to $1=$ dislike extremely.

\section{Statistical Analysis}

Completely randomized analysis of variance (ANOVA), Mean separation and comparison was done using SPSS (Version 20.0). Significance was accepted at $\mathrm{p}$ $<0.05$ and results were expressed as mean \pm standard deviation of the mean.

\section{Results}

\subsection{Isolation and Screening for Folate-Producing Isolates from Fermented Maize Slurry}

Folate producing lactic acid bacteria and yeasts were obtained from the fermentation of maize slurry. The isolates were resistant to the folate analogue, methotrexate and possessed the ability to grow in Folic Acid Casei Medium. Among the lactic acid bacteria, Isolate X13 produced the highest quantity of folate with $40.65 \mu \mathrm{g} / \mathrm{ml}$, while Isolate L21 the least of $10.98 \mu \mathrm{g} / \mathrm{ml}$. For the yeasts, Isolate Y77 was the highest folate producer with $52.40 \mu \mathrm{g} / \mathrm{ml}$, while the least was Isolate $\mathrm{Y} 47$, which produced $11.94 \mu \mathrm{g} / \mathrm{ml}$ (Table 1 ).

\subsection{Safety Assessments and Genotypic Identification of the Selected Isolates}

The selected isolates Lactobacillus sp. X13, Pediococcus sp. L73, Candida sp. Y77 and Candida sp. Y74 were selected based on their high folate-producing capacity. Table 
2 shows that they were all negative to haemolytic, DNase and gelatinase activities. The isolates were genotypically characterised with accession numbers as Lactobacillus plantarum X13 (MH431914), Pediococcus pentosaceus L73 (MH431915), Candida parapsilosis Y77 (MH443280) and Candida tropicalis Y74 (MH443281).

\subsection{Microbial Count, pH and Titratable Acidity of the Fermenting Maize Slurry}

Table 3 shows the microbial count, $\mathrm{pH}$ and titratable acidity of the fermented

Table 1. Folate production of lactic acid bacteria and yeasts isolates from ogi.

\begin{tabular}{|c|c|c|c|c|c|}
\hline \multicolumn{3}{|c|}{ Lactic acid bacteria } & \multicolumn{3}{|c|}{ Yeasts } \\
\hline Isolates & $\begin{array}{l}\text { Growth in } \\
\text { FACM }\end{array}$ & $\begin{array}{l}\text { Folate concentration } \\
\qquad(\mu \mathrm{g} / \mathrm{ml})\end{array}$ & Isolates & $\begin{array}{l}\text { Growth in } \\
\text { FACM }\end{array}$ & $\begin{array}{l}\text { Folate concentration } \\
\qquad(\mu \mathrm{g} / \mathrm{ml})\end{array}$ \\
\hline M6 & + & $25.89 \pm 0.69$ & Y75 & + & $45.52 \pm 0.84$ \\
\hline M70 & + & $19.07 \pm 0.12$ & Y3 & + & $44.36 \pm 0.55$ \\
\hline $\mathrm{X} 13$ & + & $40.65 \pm 0.76$ & Y78 & + & $33.09 \pm 1.70$ \\
\hline L15 & + & $26.80 \pm 0.60$ & Y77 & + & $52.40 \pm 0.32$ \\
\hline L9 & + & $30.89 \pm 0.07$ & Y14 & + & $20.91 \pm 1.20$ \\
\hline L3 & + & $21.44 \pm 0.31$ & Y02 & + & $47.32 \pm 0.64$ \\
\hline $\mathrm{L} 4$ & + & $28.42 \pm 0.37$ & Y71 & + & $39.02 \pm 0.60$ \\
\hline L12 & + & $24.98 \pm 0.21$ & Y01X & + & $32.45 \pm 1.36$ \\
\hline L13 & + & $12.13 \pm 0.67$ & Y5 & + & $36.95 \pm 1.23$ \\
\hline L73 & + & $36.42 \pm 0.62$ & Y73B & + & $44.98 \pm 0.12$ \\
\hline L77 & + & $14.23 \pm 0.56$ & Y74 & + & $51.79 \pm 0.33$ \\
\hline M11 & + & $32.48 \pm 0.43$ & Y11 & + & $33.56 \pm 0.66$ \\
\hline M80 & + & $16.42 \pm 0.39$ & Y04 & + & $15.57 \pm 0.29$ \\
\hline $\mathrm{L} 20$ & + & $11.22 \pm 0.24$ & Y7 & + & $13.54 \pm 0.64$ \\
\hline L79 & + & $14.05 \pm 0.31$ & Y31 & + & $18.62 \pm 0.41$ \\
\hline $\mathrm{L} 21$ & + & $10.98 \pm 0.36$ & Y32 & + & $23.73 \pm 0.39$ \\
\hline L31 & + & $12.18 \pm 0.50$ & Y47 & + & $11.94 \pm 0.09$ \\
\hline L32 & + & $18.67 \pm 0.63$ & Y34 & + & $22.98 \pm 0.12$ \\
\hline
\end{tabular}

FACM: Folic Acid Casei Medium; Values represent the mean \pm standard deviation of the mean of three independent experiments. +: Positive

Table 2. Safety Assessment of the high folate-producing strains from ogi used as starters.

\begin{tabular}{cccc}
\hline Strains & Haemolysis & Gelatinase & DNase \\
Lactobacillus plantarum X13 & $\gamma$ & - & - \\
Pediococcus pentosaceus $\mathrm{L} 73$ & $\gamma$ & - & - \\
Candida parapsilosis $\mathrm{Y} 77$ & $\gamma$ & - & - \\
Candida tropicalis $\mathrm{Y74}$ & $\gamma$ & - & - \\
\hline
\end{tabular}

$\gamma$-haemolysis: Negative. 
Table 3. Microbial count, $\mathrm{pH}$ and titratable acidity of the maize slurry fermented with folate producing microorganisms.

\begin{tabular}{|c|c|c|c|c|c|c|c|c|c|c|c|c|}
\hline \multirow{2}{*}{ Samples } & \multicolumn{4}{|c|}{ Total viable count $\left(\log \mathrm{cfu} \mathrm{mL}^{-1}\right)$} & \multicolumn{4}{|c|}{$\mathrm{pH}$} & \multicolumn{4}{|c|}{ Titratable Acidity $\left(\mathrm{g} \mathrm{L}^{-1}\right)$} \\
\hline & $0 \mathrm{~h}$ & $24 \mathrm{~h}$ & $48 \mathrm{~h}$ & $72 \mathrm{~h}$ & $0 \mathrm{~h}$ & $24 \mathrm{~h}$ & $48 \mathrm{~h}$ & $72 \mathrm{~h}$ & $0 \mathrm{~h}$ & $24 \mathrm{~h}$ & $48 \mathrm{~h}$ & $72 \mathrm{~h}$ \\
\hline A & 8.0 & 9.16 & 9.18 & 10.36 & 6.12 & 4.91 & 4.01 & 3.83 & 0.23 & 0.67 & 0.89 & 0.93 \\
\hline B & 8.0 & 9.06 & 9.30 & 10.15 & 6.12 & 5.02 & 4.65 & 4.01 & 0.23 & 0.41 & 0.59 & 0.89 \\
\hline C & 8.0 & 9.17 & 9.83 & 10.07 & 6.12 & 5.01 & 4.00 & 3.83 & 0.33 & 0.65 & 0.86 & 0.94 \\
\hline $\mathrm{D}$ & 8.0 & 9.05 & 9.42 & 10.22 & 6.12 & 5.01 & 4.78 & 3.98 & 0.23 & 0.5 & 0.68 & 0.84 \\
\hline E & 8.0 & 10.47 & 10.56 & 10.58 & 6.12 & 5.23 & 4.79 & 4.06 & 0.20 & 0.7 & 0.86 & 0.98 \\
\hline $\mathrm{F}$ & 8.0 & 10.43 & 10.58 & 10.60 & 6.12 & 5.01 & 4.65 & 3.91 & 0.25 & 0.93 & 1.17 & 1.3 \\
\hline G & ND & ND & ND & ND & 6.12 & 5.9 & 4.00 & 3.60 & 0.25 & 1.1 & 1.2 & 1.6 \\
\hline
\end{tabular}

This result represents the mean of data obtained from three independent experiments. ND: Not determined; A: Maize slurry fermented with Lactobacillus plantarum X13; B: Maize slurry fermented with Candida parapsilosis Y77; C: Maize slurry fermented with Pediococcus pentosaceus L73; D: Maize slurry fermented with Candida tropicalis Y74; E: Maize slurry fermented with Candida tropicalis Y74 and Lactobacillus plantarum X13; F: Maize slurry fermented with Candida parapsilosis Y77 and Pediococcus pentosaceus L73; G: Spontaneously fermented maize slurry.

maize slurry with mixed and single starter cultures. It was observed that the microbial count of these samples increased as the fermentation progressed. The highest microbial count for all samples was recorded after $72 \mathrm{~h}$ of fermentation, while the least microbial count was observed at the onset of fermentation.

The $\mathrm{pH}$ of these samples was observed to be decreasing as the fermentation time progressed. All samples had their lowest $\mathrm{pH}$ at $72 \mathrm{~h}$ and the highest at $0 \mathrm{~h}$. Sample $\mathrm{G}$ which was the spontaneously fermented maize slurry had the least $\mathrm{pH}$ value of 3.60 after $72 \mathrm{~h}$ of fermentation while all the samples had the highest $\mathrm{pH}$ value of 6.12 at the onset of fermentation.

The titratable acidity of the fermenting samples was observed to increase as the fermentation progressed. The least titratable acidity value of $0.20 \mathrm{~g} / \mathrm{l}$ was observed at the onset of the fermentation in Sample E, which was the maize slurry fermented with the combination of Candida tropicalis Y74 and Lactobacillus plantarum X13. After $72 \mathrm{~h}$ of fermentation, Sample G, which was the spontaneously fermented maize slurry, had the highest titratable value of $1.6 \mathrm{~g} / \mathrm{l}$.

\subsection{Total Reducing Sugars of the Fermenting Samples}

It can be deduced from Figure 1 that there was an increase in the total reducing sugars in all fermenting samples. The lowest value of the amount of total reducing sugars was observed at the $0 \mathrm{~h}$ of fermentation, while the highest amount of total reducing sugars for each sample was observed at the $72 \mathrm{~h}$ of fermentation.

\subsection{Folate Concentration of the Fermenting Samples}

Table 4 shows the effect of fermentation time on the folate production in the controlled and spontaneously fermented maize slurries. Changes in the folate concentration of the ogi samples was observed as the fermentation progressed. 


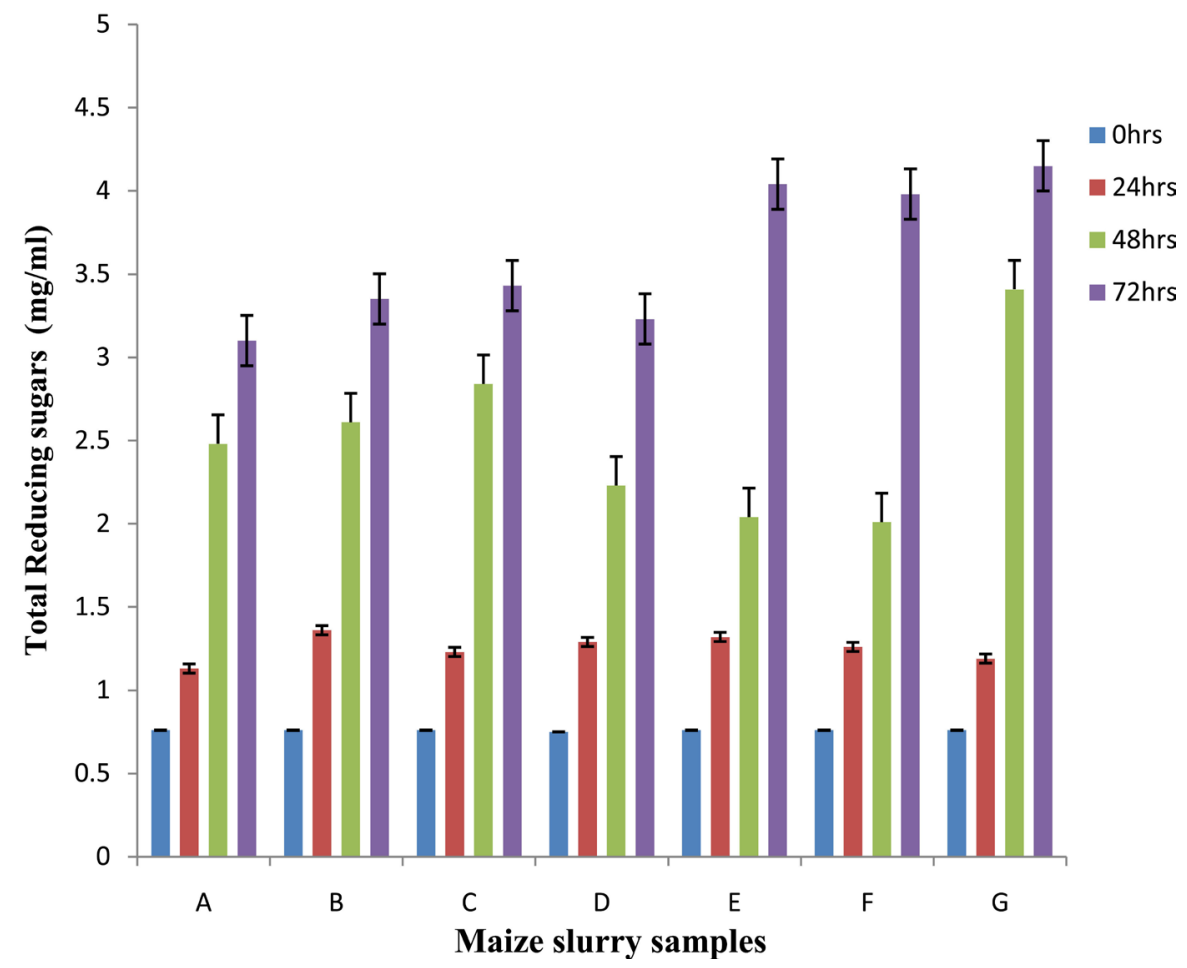

Bars represent the mean and standard deviations of three independent experiments. A: Maize slurry fermented with Lactobacillus plantarum X13; B: Maize slurry fermented with Candida parapsilosis Y77; C: Maize slurry fermented with Pediococcus pentosaceus L73; D: Maize slurry fermented with Candida tropicalis Y74; E: Maize slurry fermented with Candida tropicalis Y74 and Lactobacillus plantarum X13; F: Maize slurry fermented with Candida parapsilosis Y77 and Pediococcus pentosaceus L73; G: Spontaneously fermented maize slurry.

Figure 1. Effect of fermentation time on the total reducing sugars of the controlled and spontaneously fermented maize slurry.

Table 4. Effect of fermentation time on the folate production of controlled and spontaneously fermented maize slurries.

\begin{tabular}{ccccc}
\hline \multirow{2}{*}{ Samples } & \multicolumn{4}{c}{ Folate concentration $(\mu \mathrm{g} / \mathrm{ml})$} \\
\cline { 2 - 5 } & $0 \mathrm{~h}$ & $24 \mathrm{~h}$ & $48 \mathrm{~h}$ & $72 \mathrm{~h}$ \\
\hline A & $12.3 \pm 0.61^{\mathrm{a}}$ & $24.63 \pm 0.45^{\mathrm{a}}$ & $22.17 \pm 0.52^{\mathrm{a}}$ & $19.04 \pm 0.31^{\mathrm{a}}$ \\
B & $12.3 \pm 0.10^{\mathrm{a}}$ & $28.79 \pm 0.76^{\mathrm{b}}$ & $25.75 \pm 0.48^{\mathrm{b}}$ & $19.40 \pm 0.14^{\mathrm{a}}$ \\
C & $12.3 \pm 0.39^{\mathrm{a}}$ & $25.75 \pm 0.33^{\mathrm{a}}$ & $21.25 \pm 0.58^{\mathrm{a}}$ & $19.97 \pm 0.71^{\mathrm{a}}$ \\
D & $12.3 \pm 0.35^{\mathrm{a}}$ & $25.13 \pm 0.49^{\mathrm{a}}$ & $24.62 \pm 0.37^{\mathrm{b}}$ & $16.97 \pm 0.78^{\mathrm{b}}$ \\
E & $12.3 \pm 0.42^{\mathrm{a}}$ & $30.97 \pm 0.31^{\mathrm{c}}$ & $28.37 \pm 0.41^{\mathrm{c}}$ & $24.14 \pm 0.14^{\mathrm{c}}$ \\
F & $12.3 \pm 0.43^{\mathrm{a}}$ & $28.36 \pm 0.38^{\mathrm{b}}$ & $25.67 \pm 0.27^{\mathrm{b}}$ & $22.55 \pm 0.24^{\mathrm{d}}$ \\
G & $12.3 \pm 0.41^{\mathrm{a}}$ & $11.9 \pm 0.37^{\mathrm{d}}$ & $6.69 \pm 0.34^{\mathrm{d}}$ & $11.20 \pm 0.74^{\mathrm{e}}$ \\
\hline
\end{tabular}

Values are mean \pm standard deviation of two determinations. Means with same alphabet down each column are not statistically significant at $\mathrm{p}<0.05$. A: Maize slurry fermented with Lactobacillus plantarum X13; B: Maize slurry fermented with Candida parapsilosis Y77; C: Maize slurry fermented with Pediococcus pentosaceus L73; D: Maize slurry fermented with Candida tropicalis Y74; E: Maize slurry fermented with Candida tropicalis Y74 and Lactobacillus plantarum X13; F: Maize slurry fermented with Candida parapsilosis Y77 and Pediococcus pentosaceus L73; G: Spontaneously fermented maize slurry. 
For samples A, B, C, D, E, F, their folate concentrations were at its peak after $24 \mathrm{~h}$ of fermentation and started to decline afterwards. Sample E had the highest folate concentration of $30.97 \mu \mathrm{g} / \mathrm{ml}$ after $24 \mathrm{~h}$ of fermentation while the least of $6.69 \mu \mathrm{g} / \mathrm{ml}$ was recorded for sample $\mathrm{G}$ after $48 \mathrm{~h}$ of fermentation.

\subsection{Sensory Evaluation of Ogi Samples}

The colour of all the samples was well accepted, as there was no significant difference in the means when compared with the spontaneously fermented ogi. Sample E, which was fermented with Lactobacillus plantarum X13 and Candida tropicalis Y74 gained high acceptability by the panelists in evaluation to the control, which is the spontaneously fermented ogi. There was no significant difference between these two samples. However, there was significant difference when the attributes of spontaneous fermented ogi was compared to samples A, B, C, D and $\mathrm{F}$ (Table 5).

\section{Discussion}

The growth of microorganisms from ogi in culture media incorporated with a folate analogue, methotrexate $(50 \mathrm{mg} / \mathrm{ml})$ is an indication that these isolates are resistant to methotrexate, which was observed to be the reason for folate production by the isolates. This is because these microorganisms utilized the folate for the production of essential elements like the DNA, RNA, mRNA to ensure their multiplication and growth. Through this process, the effect of the competitive inhibition of the enzyme dihydrofolate reductase, responsible for the production of folates was completely neutralized [30]. The color change exhibited by the isolates during the screening for folate production is due to the formation of complex as a result of the diazotization reaction of para-aminobenzoic acid,

Table 5. Sensory evaluation of ogi produced from spontaneous and controlled fermentation using the selected starter cultures.

\begin{tabular}{|c|c|c|c|c|c|c|}
\hline \multirow{2}{*}{ Samples } & \multicolumn{6}{|c|}{ Attributes } \\
\hline & Colour & Taste & Flavour & Aroma & Texture & Overall Acceptability \\
\hline A & $5.90 \pm 0.86^{\mathrm{a}}$ & $5.70 \pm 1.0^{\mathrm{a}}$ & $5.30 \pm 0.67^{a}$ & $5.60 \pm 0.63^{\mathrm{a}}$ & $4.80 \pm 0.63^{\mathrm{a}}$ & $5.30 \pm 0.69^{\mathrm{a}}$ \\
\hline B & $6.10 \pm 1.0^{\mathrm{ab}}$ & $6.00 \pm 1.0^{\mathrm{a}}$ & $5.90 \pm 1.0^{\mathrm{a}}$ & $5.70 \pm 0.47^{\mathrm{a}}$ & $5.00 \pm 1.0^{\mathrm{a}}$ & $5.00 \pm 0.87^{\mathrm{a}}$ \\
\hline $\mathrm{C}$ & $6.20 \pm 0.94^{\mathrm{ab}}$ & $6.40 \pm 0.9^{\mathrm{a}}$ & $6.00 \pm 0.87^{a}$ & $5.80 \pm 0.96^{\mathrm{a}}$ & $5.40 \pm 0.94^{\mathrm{a}}$ & $6.00 \pm 1.22^{\mathrm{a}}$ \\
\hline $\mathrm{D}$ & $6.40 \pm 0.84^{\mathrm{ab}}$ & $6.60 \pm 0.95^{\mathrm{a}}$ & $6.10 \pm 0.73^{\mathrm{a}}$ & $6.00 \pm 1.02^{\mathrm{a}}$ & $5.50 \pm 1.35^{\mathrm{ab}}$ & $6.70 \pm 0.94^{\mathrm{a}}$ \\
\hline $\mathrm{E}$ & $7.80 \pm 1.4^{\mathrm{ab}}$ & $6.70 \pm 1.77^{\mathrm{ab}}$ & $6.50 \pm 0.17^{a}$ & $6.50 \pm 1.71^{\mathrm{ab}}$ & $6.90 \pm 0.94^{\mathrm{ab}}$ & $7.00 \pm 0.76^{b}$ \\
\hline $\mathrm{F}$ & $7.20 \pm 0.63^{\mathrm{ab}}$ & $6.10 \pm 0.82^{\mathrm{ab}}$ & $6.60 \pm 1.13^{b}$ & $6.10 \pm 1.10^{\mathrm{b}}$ & $7.00 \pm 2.11^{\mathrm{b}}$ & $6.60 \pm 0.73^{a}$ \\
\hline G & $7.30 \pm 0.94^{\mathrm{ab}}$ & $7.10 \pm 0.94^{\mathrm{b}}$ & $6.70 \pm 0.14^{\mathrm{a}}$ & $6.90 \pm 1.01^{\mathrm{b}}$ & $7.10 \pm 1.28^{\mathrm{b}}$ & $7.80 \pm 0.66^{\mathrm{b}}$ \\
\hline
\end{tabular}

Means with the same superscript alphabet within the same column are not significantly different at $\mathrm{p}<$ 0.05. A: Ogi fermented with Lactobacillus plantarum X13; B: Ogi fermented with Candida parapsilosis Y77; C: Ogi fermented with Pediococcus pentosaceus L73; D: Ogi fermented with Candida tropicalis Y74; E: Ogi fermented with Candida tropicalis Y74 and Lactobacillus plantarum X13; F: Ogi fermented with Candida parapsilosis $\mathrm{Y77}$ and Pediococcus pentosaceus L73; G: Spontaneously fermented ogi. 
obtained after the reduction of the folic acid (produced by the isolates in the broth) and 3-aminophenol [21].

A comparison of the quantity of folate produced by lactic acid bacteria and yeasts in their respective growth media indicates that the yeast isolates from ogi are better folate producers than the lactic acid bacteria. This is because the average concentration of folate produced by the yeast cells was $28.80 \mu \mathrm{g} / \mathrm{ml}$ while the lactic acid bacteria produced $21.27 \mu \mathrm{g} / \mathrm{ml}$. These findings is in agreement with the reports of Kariluoto et al. [31] who observed that yeasts are better folate producers in a growth medium compared to other microorganisms from oat bran. The differences in the quantity of folate produced could be associated with the nutrients in the culture media.

In this study, Lactobacillus plantarum X13 was observed to be the highest folate producer in MRS medium. In ben salaaga, African cereal gruel of Burkina Faso, the concentration of $110 \mathrm{ng} / \mathrm{ml}$ and $120 \mathrm{ng} / \mathrm{ml}$ of folates was produced by Lactobacillus fermentum and Lactobacillus plantarum respectively in MRS medium [16]. In another study, Lactobacillus plantarum and Lactococcus sp. isolated from Malaysian tapai ubi produced $8.608 \mu \mathrm{g} / \mathrm{L}$ and $10.71 \mu \mathrm{g} / \mathrm{L}$ respectively in an MRS medium [32]. In this study, Candida parapsilosis Y77 and Candida tropicalis Y74 were the highest folate producers, with a production of $52.40 \mu \mathrm{g} / \mathrm{ml}$ and $51.79 \mu \mathrm{g} / \mathrm{ml}$ of folates respectively. The folate concentration of $1760 \mathrm{ng} / \mathrm{ml}$ was produced by Saccharomyces cerevisiae in yeast peptone dextrose (YPD) medium from the in situ enrichment of folates by yeasts isolated from oat and barley matrices [31]. The differences in folate concentration produced by the microorganisms in culture medium in the various studies maybe asserted to be strain dependent [11] [16]. The differences are linked to the methods adopted in these studies, as the concentration of folates obtained via high performance liquid chromatography (HPLC) and ultra HPLC usually have more specific quantification than those obtained through the microbiological assay and spectrophotometric methods. This is due to the variations in the sensitivity of the methods because HPLC and ultra HPLC target the specific folate produced than the crude vitamins detection using the microbiological assay and spectrophotometric methods [33] [31].

The unfermented maize slurry had the folate content of $12.3 \mu \mathrm{g} / \mathrm{ml}$, which is lower than the folate content of maize, which is $19 \mu \mathrm{g} / 100 \mathrm{~g}$ of fresh weight. This confirms the loss of folates during the milling stages while processing the grain for fermentation [34]. This could be due to the loss of aleuronic layer of the grain, which is known to contain several micronutrients such as riboflavin, lysine, methionine and pathothenic acid [2].

Folate quantification of the fermenting maize slurry showed that microorganisms are responsible for folate production in the fermenting slurry as there was increase in the folate concentration of the slurry. This finding is in agreement with the report of Kariluoto et al. [33] who observed that the presence of yeast species of Candida and Saccharomyces led to the increase of folate levels in rye sourdough during fermentation. In another study, these yeast species were ob- 
served to increase the folate levels of togwa, a Tanzanian cereal based fermented food during fermentation [14]. Increase in the folate levels of fermented milk have been associated with the folate producing activities of lactic acid bacteria such as Lactobacillus delbrueckii var. bulgaricus and Lactococcus sp. [11]. The quantity produced in the slurry was quite less than that produced in the culture broth; this indicates that the folate producing capacity is dependent upon the composition of food matrix, the medium composition or the availability of folate precursors. As the culture medium; de Man Rogosa Sharpe (MRS) and Malt Extract broth contains yeast extracts made up of para-aminobenzoic acid $(6 \mu \mathrm{g} / \mathrm{ml})$ and glutamic acid $(2 \mathrm{mg} / 100 \mathrm{~g})$, which are the major precursors for the production of folates by most microorganisms [16]. The availability of this compounds in considerable amounts affects the quantity of folates produced by some microorganisms like Lactococcus lactis, which its folate producing capacity increased by two folds in the presence of para-aminobenzoic acid [35].

Furthermore, in this study, the folate-producing mixed starter cultures of lactic acid bacteria and yeasts were observed to increase the folate content of a fermented food more than when either a lactic acid bacterium or yeast was used as a sole starter. Statistically, there was a significant difference in the folate production by mixed starter cultures than in single starters. This finding is in agreement with the report of Greppi et al. [17] who observed an increase in the folate content in the co-fermentation of Lactobacillus fermentum and Pichia kudriavzevii in ben salaaga, a cereal based fermented gruel in Burkina Faso. A similar result was obtained when folate-producing Streptococcus thermophilus and Lactobacillus delbrueckii subsp. bulgaricus were used as starter cultures for milk fermentation [11]. A combination of L. rhamnosus LC-705 and Saccharomyces cerevisiae ABM5131 (in 3.5\% oat bran solution with $2 \%$ added glucose) produced 6-fold more folate than the LAB and yeast when used singly [36]. The highest folate concentration in rye sourdough was observed after fermentation with mixed cultures, which consisted of naturally occurring bacteria and yeasts while folate concentrations were significantly lower in sourdough fermented by monocultures of lactic acid bacteria and yeasts [37].

In this study, the folate content of all the samples reached its peak of about 2 3 fold (40\% - 60\%) increase when compared to the unfermented slurry, after 24 $\mathrm{h}$ of fermentation and a decline was observed afterwards. This decline could be that some folate-producing microorganisms also consumed folates, because it is needed for metabolism and growth [38] [39]. The decline in folate concentration could be due to the decrease in the $\mathrm{pH}$ of the fermenting maize slurry, which became acidic. This condition had been reported to either suppress synthesis of folates by microorganisms or destroy other forms of folates which are less stable in the acidic conditions such as 5-methyltetrahydrofolate $\left(5-\mathrm{CH}_{3} \mathrm{H}_{4}\right.$ Folate) [33] This result is in agreement with the findings of Laino et al. [11] who reported that folate production by folate producing starter culture reached its peak after $24 \mathrm{~h}$ of fermentation. This is contrary to the findings of Hjortmo et al. [14] who 
observed a continuous increase in folate concentration in togwa, a Tanzanian fermented gruel, after $24 \mathrm{~h}$ of fermentation using monocultures of Saccharomyces, Candida and Klyveromyces as single starters. In addition, they recorded a 23 -fold increase in folate content of the fermenting maize meal after $46 \mathrm{~h}$ of fermentation. On the contrary, in this study, the folate concentration of the spontaneously fermenting maize slurry was erratic during the fermentation period. There was a decrease in folate content after 24 and $48 \mathrm{~h}$ of fermentation, and an increase after $72 \mathrm{~h}$ of fermentation. This indicates the complexity associated with spontaneous fermentation. The irregularity in the folate concentration could be due to the presence of a mixed population of folate-synthesizing and folate consuming microorganisms. Nevertheless, the rise in folate content could be associated to the lysis of intracellular folate producers due to adverse conditions like low $\mathrm{pH}$. This led to the release of extra folate into the cereal matrix as the fermentation period progressed to the third day [16].

The ogi samples fermented with Candida tropicalis Y74 and Candida parapsilosis Y77 had high mean values in the aroma and flavour. This confirms the contribution of yeast in the development of flavour in cereal-based fermented foods due to the production of certain volatile compounds like acetoin and acetaldehyde [40]. The contrast in the low and high mean values of the ogi samples for general acceptability could be due to single starters of lactic acid bacteria and yeasts. The high mean values of ogi samples produced by the co-fermentation of Candida tropicalis Y74 and Lactobacillus plantarum X13 confirms the roles mixed starter cultures play in improving the general acceptability of ogi as well as other cereal-based fermented foods as observed in previous studies [2] [41] [42].

\section{Conclusion}

This study shows that microorganism from ogi could produce folate both in growth media and the fermenting mash. Fermentation time and $\mathrm{pH}$ were the factors that influenced their folate-producing capacity. The right combination of folate-producers as starter cultures elevated folate content in cereal based fermented foods without compromising their general acceptability. This suggests that, folate enriched ogi could serve as a strategy to increase folate intake by contributing to the daily folate requirement especially in developing countries where folic acid fortification of foods is hardly reported. It can be used for intervention studies or prevention strategies to curb folate deficiency. The selected organisms used as starter cultures can be bioengineered to improve their performance as folate producers for the improvement of the folate content of these fermented foods. This may involve blocking the chorismate-consuming pathways or shunt off their phenylalanine synthesis pathway or even trigger the over expression of genes in the folate operon using a cost-effective genetic method. In an effort to curtail folate deficiency, the data generated from this work can be used as baseline for the pilot studies in the industrial production of bio-enriched ogi as functional food products. Focus may be on maintaining optimum condi- 
tions during fermentation and processing that will enhance folate production by the starter cultures in order to obtain maximum results.

\section{Acknowledgements}

The authors appreciate Prof. Christophe Lacroix of the Laboratory of Food Biotechnology, Institute of Food Nutrition and Health, ETH, Zurich Switzerland for the assistance in the molecular characterisation of the selected strains used in this study. The authors gratefully acknowledge Prof. Chinedum Babalola of Centre for Drug Discovery, Development and Production (CDDP) of the Faculty of Pharmacy, University of Ibadan, Oyo State for the provision of some of the chemicals used in this study.

\section{Conflicts of Interest}

The authors declare no conflicts of interest regarding the publication of this paper.

\section{References}

[1] Odunfa, S.A. and Oyewole, O.B. (1998) African Fermented Foods. In: Woods, J.B., Ed., Microbiology of Fermented Foods, Blackie Academic and Professional, London, 713-752. https://doi.org/10.1007/978-1-4613-0309-1_23

[2] Teniola, O.D. and Odunfa, S.A. (2001) The Effects of Processing Methods on the Levels of Lysine, Methionine and the General Acceptability of Ogi Processed Using Starter Cultures. International Journal of Food Microbiology, 63, 1-9. https://doi.org/10.1016/S0168-1605(00)00321-4

[3] Inyang, C.U. and Idoko, C.A. (2006) Assessment of the Quality of Ogi Made from Malted Millet. African Journal of Biotechnology, 5, 2334-2337.

[4] Guyot, J.-P. (2012) Cereal-Based Fermented Foods in Developing Countries: Ancient Foods for Modern Research. International Journal of Food Science \& Technology, 47, 1109-1114. https://doi.org/10.1111/j.1365-2621.2012.02969.x

[5] Odunfa, S.A., Adeniran, S.A., Teniola, O.D. and Nordstrom, J. (2001) Evaluation of Lysine and Methionine Production in Some Lactobacilli and Yeasts from Ogi. International Journal of Food Microbiology, 63, 159-163. https://doi.org/10.1016/S0168-1605(00)00320-2

[6] USDA-ARS (US Department of Agriculture, Agricultural Research Service) (2012) USDA National Nutrient Database for Standard Reference, Release 25. Nutrient Data Laboratory. http://www.ars.usda.gov/ba/bhnrc/ndl

[7] Saubade, F., Hemery, Y.M., Guyot, J.-P. and Humblot, C. (2017) Lactic Acid Fermentationas a Tool for Increasing the Folate Content of Foods. Critical Reviews in Food Science and Nutrition, 12, 52-57.

[8] Saubade, F., Hemery, Y.M., Rochette, I., Guyot, J.P. and Humblot, C. (2018) Influence of Fermentation and Other Processing Steps on the Folate Content of a Traditional African Cereal-Based Fermented Food. International Journal of Food Microbiology, 266, 79-86. https://doi.org/10.1016/j.ijfoodmicro.2017.11.015

[9] Papastoyiannidis, G., Polychroniadou, A., Michaelidou, A. and Alichanidis, E. (2004) Fermented Milks Fortified with B-Group Vitamins: Vitamin Stability and Effect on Resulting Products. Food Science and Technology International, 12 
521-529. https://doi.org/10.1177/1082013206073274

[10] Blenkowe, H., Cousens, S., Modell, B. and Lawn, J. (2010) Folic Acid to Reduce Neonatal Mortality from Neural Tube Disorders. International Journal of Epidemiology, 39, i110-i121. https://doi.org/10.1093/ije/dyq028

[11] Laiño, J.E., LeBlanc, J.G. and Savoy de Giori, G. (2012) Production of Natural Folates by Lactic Acid Bacteria Starter Cultures Isolated from Artisanal Argentinean Yogurts. Canadian Journal of Microbiology, 58, 581-588. https://doi.org/10.1139/w2012-026

[12] Safi, J., Joyeux, L. and Chalouhi, G.E. (2012) Periconceptional Folate Deficiency and Implications in Neural Tube Defects. Journal of Pregnancy, 12, 209-220. https://doi.org/10.1155/2012/295083

[13] Bailey, L.B., Stover, P.J., McNulty, H., Fenech, M.F., Gregory, J.F., Mills, J.L., Pfeiffer, C.M., Fazili, Z., Zhang, M. and Ueland, P.M. (2015) Biomarkers of Nutrition for Development-Folate Review. Journal of Nutrition, 145, 1636S-1680S. https://doi.org/10.3945/jn.114.206599

[14] Hjortmo, S., Hellstrom, A.M. and Andlid, T.A. (2008) Production of Folates by Yeast in Tanzanian Fermented Togwa. Federation of European Microbiological Studies, 8, 781-787. https://doi.org/10.1111/j.1567-1364.2008.00398.x

[15] Salvucci, E., LeBlanc, J.G. and Pérez, G. (2016) Technological Properties of Lactic Acid Bacteria Isolated from Raw Cereal Material. LWT Food Science and Technology, 70, 185-191. https://doi.org/10.1016/j.lwt.2016.02.043

[16] Greppi, A., Hemery, Y., Berrazaga, I., Almaksour, Z. and Humblot, C. (2017) Ability of Lactobacilli Isolated from Traditional Cereal-Based Fermented Food to Produce Folate in Culture Media under Different Growth Conditions. Food Science and Technology, 86, 277-284. https://doi.org/10.1016/j.lwt.2017.08.007

[17] Greppi, A., Saubade, F., Botta, C., Humblot, C., Guyot, J.-P. and Cocolin, L. (2017) Potential Probiotic Pichia kudriavzevii Strains and Their Ability to Enhance Folate Content of Traditional Cereal-Based African Fermented Food. Food Microbiology, 62, 169-177. https://doi.org/10.1016/j.fm.2016.09.016

[18] Harrigan, W.F. and McCance, M.F. (1966) Laboratory Methods in Food and Dairy Microbiology. 2nd Edition, Academic Press, London.

[19] Kurtzman, C.P., Fell, J.W. and Boekhout, T. (2011) The Yeasts: A Taxonomic Study. 5th Edition, 3 Vol., Elsevier Science Publishers, Amsterdam.

[20] Wood, B.J.B. and Holzapfel, W.H. (1995) The Genera of Lactic Acid Bacteria. Vol. 2, Blackie Academic and Professional Glasgow.

https://doi.org/10.1007/978-1-4615-5817-0

[21] Ruengsitagoon, W. and Hattanat, N. (2012) Simple Spectrophotometric Method for Determination of Folic Acid. 4th Annual Northeast Pharmacy Research Conference of Pharmacy Profession in Harmony, 11-12 February 2012, 281.

[22] Kodi, C., Gothandam, K.M. and Prabakaran, G. (2015) Identification and Characterization of Folic Acid Producing Potential Starter For Curd Fermentation. International Journal of Current Microbiology and Applied Sciences, 4, 118-130.

[23] Yoon, M.Y., Kim, Y.J. and Hwang, H.J. (2008) Properties and Safety Aspects of Enterococcus faecium Strains Isolated from Chungkukjang, a Fermented Soy Product. LWT, Food Science and Technology, 41, 925-933. https://doi.org/10.1016/j.lwt.2007.05.024

[24] Banwo, K., Sanni, A.I. and Tan, H.R. (2013) Technological Properties and Probiotic Potential of Enterococcus faecium Strains Isolated from Cow Milk. Journal of Ap- 
plied Microbiology, 114, 229-241. https://doi.org/10.1111/jam.12031

[25] Gupta, H. and Malik, R.K. (2007) Incidence of Virulence in Bacteriocin Producing Enterococcal Isolates. Lait, 87, 587-601. https://doi.org/10.1051/lait:2007031

[26] Kurtzman, C.P. and Robnett, C.J. (1998) Identification and Phylogeny of Ascomycetous Yeasts from Analysis of Nuclear Large Subunit (26S) Ribosomal DNA Partial Sequences. Antonie van Leeuwenhoek, 73, 331-371. https://doi.org/10.1023/A:1001761008817

[27] Goldenberger, D., Perschil, I., Ritzler, M. and Altwegg, M. (1995) A Simple Universal DNA Extraction Procedure Using SDS and Proteinase K Is Compatible with Direct PCR Amplification. Genome Research, 4, 368-370. https://doi.org/10.1101/gr.4.6.368

[28] AOAC (1990) Official Method of Analysis. 15th Edition, Association of Official Analytical Chemists, Washington DC, 442-450.

[29] Miller, G.L. (1959) Use of Di-Nitrosalicyclic Reagent for Determination of Reducing Sugars. Analytical Chemistry, 31, 426-428. https://doi.org/10.1021/ac60147a030

[30] Wegkamp, A., Smid, E.J. and de Vos, W.M. (2006) Bacteria That Naturally Overproduce Folate. Patent WO2006093408.

[31] Kariluoto, S., Edelmann, M., Nyström, L., Sontag-Strohm, T., Salovaara, H., Kivelä, R. and Piironen, V. (2014) In Situ Enrichment of Folate by Microorganisms in Beta-Glucan Rich Oat and Barley Matrices. International Journal of Food Microbiolo$g y$, 176, 38-48. https://doi.org/10.1016/j.ijfoodmicro.2014.01.018

[32] Nor, N.M., Mousavi, S., Sadegh, M.R. and Foo, H.L. (2008) Screening of Lactic Acid Bacteria for Folic Acid Production. 30 th Symposium of Malaysian Society of Microbiology, Kuantan, 16-19 August 2008, 45-50.

[33] Kariluoto, S., Vahteristo, L., Salovaara, H., Katina, K., Liukkonen, K. and Piironen V. (2004) Effect of Baking Method and Fermentation on Folate Content of Rye and Wheat Breads. Cereal Chemistry, 81, 134-139. https://doi.org/10.1094/CCHEM.2004.81.1.134

[34] Truswell, A.S. (2002) Cereal Grains and Coronary Heart Disease. European Journal of Clinical Nutrition, 56, 1-14. https://doi.org/10.1038/sj.ejcn.1601283

[35] Sybesma, W., Starrenburg, M., Tijsseling, L., Hoefnagel, M.H.N. and Hugenholtz, J. (2003) Effects of Cultivation Conditions on Folate Production by Lactic Acid Bacteria. Applied Environmental Microbiology, 69, 4542-4548. https://doi.org/10.1128/AEM.69.8.4542-4548.2003

[36] Korhola, M., Hakonen, R., Juuti, K., Edelmann, M., Kariluoto, S., Nyström, L., Sontag-Strohm, T. and Piironen, V. (2014) Production of Folate in Oat Bran Fermentation by Yeasts Isolated from Barley and Diverse Foods. Journal of Applied Microbiology, 117, 679-689. https://doi.org/10.1111/jam.12564

[37] Kariluoto, S., Aittamaa, M., Korhola, M., Salovaara, H., Vahteristo, L. and Piironen, V. (2006) Effects of Yeasts and Bacteria on the Levels of Folates in Rye Sourdoughs. International Journal of Food Microbiology, 106, 137-143. https://doi.org/10.1016/j.ijfoodmicro.2005.06.013

[38] Gangadharan, D. and Nampoothiri, K.M. (2011) Folate Production Using Lactococcus lactis sp cremoris with Implications for Fortification of Skim Milk and Fruit Juices. Food Science Technology, 12, 1859-1864. https://doi.org/10.1016/j.lwt.2011.05.002

[39] Kundu, S. and Deep, S. (2014) Comparative Studies on Folate Production and Parameter Optimization in Fermented Milk from Yoghurt Starter Culture. Interna- 
tional Journal of Engineering Sciences and Research Technology, 3, 653-660.

[40] Blandino, A., Al-Aseeri, M.E., Pandiella, S.S., Cantero, D. and Webb, C. (2003) Cereal-Based Fermented Foods and Beverages. Food Research International, 36, 527-543. https://doi.org/10.1016/S0963-9969(03)00009-7

[41] Holzapfel, W.H. (2002) Appropriate Starter Culture Technologies for Small-Scale Fermentation in Developing Countries. International Journal of Food Microbiolo$g y, 75,197-212$. https://doi.org/10.1016/S0168-1605(01)00707-3

[42] Vieira-Dalodé, G., Jespersen, L., Hounhouigan, D.J., Lange, M.P., Nago, M.C. and Jakobsen, M. (2007) Lactic Acid Bacteria and Yeasts Associated with Gowé Production from Sorghum in Bénin. Applied Journal of Microbiology, 103, 342-349.

https://doi.org/10.1111/j.1365-2672.2006.03252.x 